\title{
Thyroid abnormality in abnormal uterine bleeding: an observational study from Medical College in Western UP, India
}

\author{
Prachi Singh ${ }^{1}$, Prashant Dubey ${ }^{2 *}$, Shweta Yadav ${ }^{1}$, Sachin Singh Yadav ${ }^{3}$
}

\begin{abstract}
${ }^{1}$ Department of Obstetrics and Gynecology, ${ }^{2}$ Department of Internal Medicine, ${ }^{3}$ Department of Community Medicine, Teerthankar Mahaveer Medical College and Research Center, Moradabad, Uttar Pradesh, India
\end{abstract}

Received: 13 November 2017

Accepted: 09 December 2017

*Correspondence:

Dr. Prashant Dubey,

E-mail: drmed6264@gmail.com

Copyright: (C) the author(s), publisher and licensee Medip Academy. This is an open-access article distributed under the terms of the Creative Commons Attribution Non-Commercial License, which permits unrestricted non-commercial use, distribution, and reproduction in any medium, provided the original work is properly cited.

\section{ABSTRACT}

Background: Abnormal Uterine Bleeding (AUB) is one of the commonest gynecological complain in reproductive age group. Menstrual abnormalities are commonly seen when there is any alteration in thyroid function. Objective of present study was to investigate the prevalence of AUB and to determine the menstrual pattern in cases with thyroid dysfunction.

Methods: The present cross sectional observational study was conducted Teerthankar Mahaveer Medical College and Research Center Moradabad. Total 400 cases presenting with AUB were included in the study. Routine blood test, ultrasonography and thyroid function tests were done in these cases.

Results: Among all the cases presenting with menstrual abnormalities $26 \%$ had hypothyroidism and $9 \%$ have hyperthyroidism and rest had euthyroid status. Menorrhagia (45.2\%) and polymenorrhoea (37.5\%) were commonest menstrual abnormality seen in cases with hypothyroidism. Most cases with hyperthyroidism presented with hypomenorrhoea $(27.8 \%)$.

Conclusions: Thyroid function abnormality is common in cases presenting with AUB and it gets relieved in correcting hormonal imbalance.

Keywords: Abnormal uterine bleeding, Hyperthyroidism, Hypothyroidism

\section{INTRODUCTION}

Menstrual disorders pose a huge burden on gynaecological OPD accounting for approximately $20 \%$ of attendance. ${ }^{1}$ Thyroid dysfunction can lead to menstrual irregularities and infertility. ${ }^{2}$ Thyroid dysfunction causes broad spectrum of reproductive disorders from abnormal sexual development, menstrual irregularities, infertility to premature menopause. ${ }^{3}$ In women with hypothyroidism, TRH induced hyperprolactinemia alter the GnRH pulsatile secretion leading to defective or delay in $\mathrm{LH}$ response leading to luteal phase defect and anovulation. Apart from effect on ovulation, hypothyroidism also causes menorrhagia by altering coagulation factors i.e., decrease in factors VII, VIII, IX, XI. ${ }^{4}$ SHBG production increases in hyperthyroidism. Hyperthyroxinemia increases the gonadotrophin response to $\mathrm{GnRH}$ and baseline gonadotrophin concentrations are also frequently elevated. The decrease in menstrual flow may also relate to effects on hemostatic factors, including the synthesis of factor VII. Despite these metabolic changes, hyperthyroid women usually maintain ovulation, according to endometrial biopsies. ${ }^{4}$

In India thyroid disorders are among the most common endocrine diseases. ${ }^{5}$ Onset of thyroid disorders increases with age and it is estimated that $26 \%$ of premenopausal women are diagnosed with thyroid disorders. ${ }^{6}$ Thyroid disorders are more common in women than in men and in older adults compared with younger age groups. ${ }^{7}$ 


\section{METHODS}

The present cross sectional observational study was conducted among patients fulfilling inclusion criteria who were attending Gynecology OPD of Teerthankar Mahaveer Medical College and Research Center Moradabad between during august 2016 to July 2017.

\section{Inclusion criteria}

All cases in reproductive age group presenting with AUB willing to participate in the study.

\section{Exclusion criteria}

- Pregnancy related complications

- H/O IUCD insertion

- Patient on hormonal contraception/drugs (antipsychotic)

- Known cases with genital malignancies

- Associated pelvic inflammatory disease

- Cases refusing to participate in the study

After taking informed consent, on a pre-deginsed performa detailed history regarding age, parity, menstrual history, onset and duration of complaints was entered. Then general physical, systemic and gynaecological examination was carried out. Cases were further subjected to routine blood investigations, pelvic ultrasound and thyroid function test.

Reference range

- $\quad \mathrm{S} \mathrm{T} 4-60-120 \mathrm{ng} / \mathrm{ml}$

- $\mathrm{S} \mathrm{T} 3-0.8-16 \mathrm{ng} / \mathrm{ml}$

- $\quad \mathrm{S}$ TSH- 0.5-5.5 mIU/ml

All data was entered in excel. Appropriate statistical test were applied.

\section{RESULTS}

According to the study majority of the cases who presented with AUB were in the age group 31-40 years (42\%) followed by 41-50 years.

Table 1: Age and parity distribution of cases.

\begin{tabular}{|lll|}
\hline Age (in years) & Number & Percentage \\
\hline$<20$ & 48 & 12 \\
\hline $21-30$ & 88 & 22 \\
\hline $31-40$ & 168 & 42 \\
\hline $41-50$ & 96 & 24 \\
\hline Parity & Number & Percentage \\
\hline Nullipara & 32 & 8 \\
\hline P1 & 44 & 11 \\
\hline P2 & 136 & 34 \\
\hline P3 & 144 & 36 \\
\hline$>$ P4 & 44 & 11 \\
\hline
\end{tabular}

Parity wise distribution of cases has shown that majority of cases with AUB were Para 3(36\%) followed by Para 2(34\%) (Table 1).

As depicted in Figure 1 out of 400 cases included in the study the most common complaint was menorrhagia $(33.75 \%)$ followed by polymenorrhoea (27.25\%) Followed by hypomenorrhoes (18.25\%) then amenorrhoea (11.75\%) and the least common complaint was metrorrhagia (9\%).

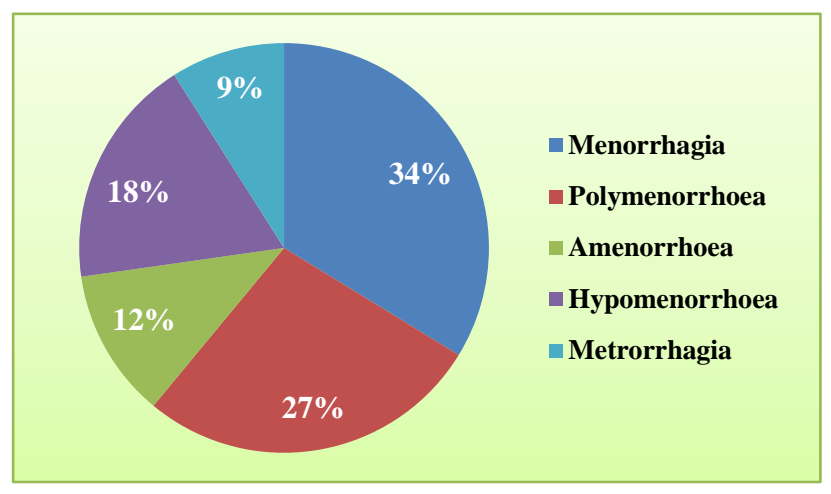

Figure 1: Pattern of menstrual irregularity.

In present study on pelvic ultrasound 108 (27\%) had pelvic structural abnormality, out of which adenomysosis was commonest (10\%), followed by fibroid (9.25\%), ovarian cyst $(5.5 \%)$ and endometrial polyp (2.25\%) (Table 2).

Table 2: Structural abnormalities.

\begin{tabular}{|lll|}
\hline Structural abnormality & Number & Percentage \\
\hline Fibroid & 37 & 9.25 \\
\hline Adenomyosis & 40 & 10 \\
\hline Ovarian cyst & 22 & 5.5 \\
\hline Endometrial polyp & 9 & 2.25 \\
\hline
\end{tabular}

On estimating the thyroid function of present study participants majority of them were euthyroid (65\%) followed by hypothyroidism $(26 \%)$ and hyperthyroidism was seen only in $9 \%$ cases who presented with AUB (Figure 2).

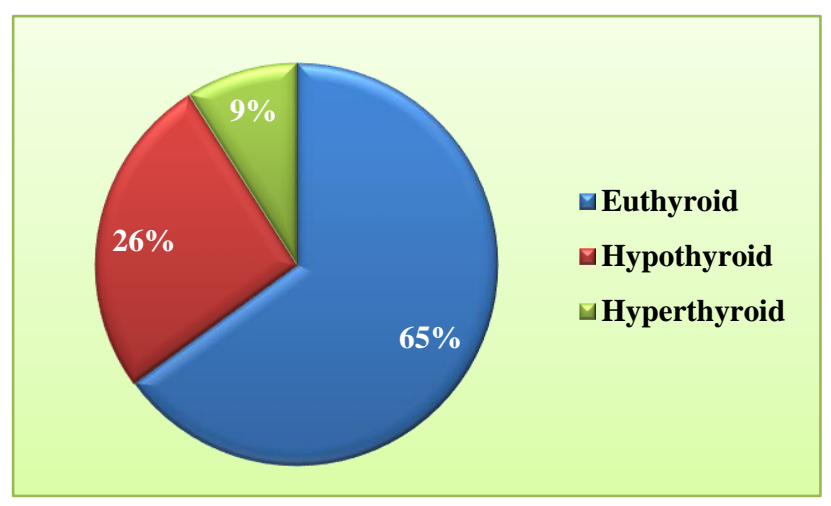

Figure 2: Distribution as per thyroid status. 
According to present study hypothyroidism was seen in $45.2 \%$ cases presenting with menorrhagia followed by polymenorrhoea $(37.5 \%)$ which in turn is followed by amenorrhoea $(10.6 \%)$ followed by hypomenorrhoea and metrorrhagia and menstrual abnormality commonest with hyperthyroidism was hypomenorrheoa (27.5\%) (Table 3).

Table 3: Pattern of bleeding in thyroid disorders.

\begin{tabular}{|llll|}
\hline Pattern of bleeding & Hypothyroidism & Hyperthyroidism & Euthyroid \\
\hline Menorrhagia & 47 & 9 & 79 \\
\hline Polymenorrhoea & 39 & 6 & 64 \\
\hline Amenorrhoea & 11 & 7 & 29 \\
\hline Hypomenorrhoea & 4 & 10 & 59 \\
\hline Metrorrhagia & 3 & 4 & 29 \\
\hline
\end{tabular}

The chi-square statistic is 36.1548 . The $\mathrm{p}$-value is .000016 . The result is significant at $\mathrm{p}<0.05$.

\section{DISCUSSION}

Thyroid dysfunction is an important cause of menstrual abnormality in females of reproductive age group as thyroid hormone play an important role in regulation of menstrual function. As per study majority of the cases who presented with AUB were in the age group 31-40 years $(42 \%)$ followed by $41-50$ years. Byna $\mathrm{P}$ et al reported that $67.2 \%$ women with AUB are in age group between $35-45$ years. $25.4 \%$ women were between age groups of $46-50$ years. $^{8}$

In the present study majority of cases were multiparous whereas only $8 \%$ were nulliparous. Similar pattern was observed by Pilli et al where $87 \%$ of women were multiparous and only $7 \%$ were nulliparous. ${ }^{9}$

Present study demonstrates prevalence of hypothyroidism in cases of AUB 26\% and that of hyperthyroidism was $9 \%$ and rest $65 \%$ cases had euthroid status. our result are comparable with earlier studies (Table 4). ${ }^{9-11}$ In a study by Pahwa et al $22 \%$ cases had hypothyroidism. ${ }^{12}$ Study done by Padmaleela et al had shown prevalence of hyperthyroidism among cases of AUB as $8.4 \% .^{13}$

Among 104 hypothyroid cases the most common menstrual abnormality observed was menorrhagia (45.2\%) followed by polymenorrhoea $(37.5 \%)$ which is similar to that of study done by Kaur et al. ${ }^{14}$

Table 4: Prevalence of thyroid dysfunction in earlier studies.

\begin{tabular}{|c|c|c|c|}
\hline Study by & Hypothyroidism (\%) & Hyperthyroidism (\%) & Euthyroid (\%) \\
\hline Present study & 26 & 9 & 65 \\
\hline Sharma et al ${ }^{10}$ & 22 & 14 & 64 \\
\hline Rani $S$ et al ${ }^{11}$ & 19 & 2 & 79 \\
\hline Byna $\mathrm{P}$ et al ${ }^{9}$ & 21.8 & 12.72 & 64.5 \\
\hline
\end{tabular}

Pahwa also observed similar pattern of menstrual abnormality in which out of 22 hypothyroid cases $16(78.9 \%)$ had menorrhagia followed by polymenorrhoea $(10.5 \%) .{ }^{12}$ On the contrary Padmaleela et al reported much less incidence of polymenorrhoea $(13.3 \%){ }^{13}$

According to present study commonest menstrual abnormality with hypothyroidism was hypomenorrheoa $(27.5 \%)$. Kaur et $\mathrm{al}^{14}$ observed that most common menstrual complain associated with hyperthyroidism was hypomenorrhoea which is similar to present study.

Limitation of study was anti TPO antibody titer being a costly investigation was not included in the study which might diagnose patients with subclinical hypothyroidism, the study was done in patients attending medical college it may not be representative of general population, hence large scale population research is recommended.

\section{CONCLUSION}

It was concluded that there is a strong correlation of thyroid dysfunction with abnormal menstrual bleeding. Thyroid dysfunction is common in cases presenting with AUB and menstrual problems gets corrected on correcting the thyroid status.

Therefore, it is important to screen all women for thyroid abnormality who are presenting with AUB especially with non-structural causes of AUB. We strongly 
recommend inclusion of thyroid function tests in the panel of tests in cases of AUB. to avoid unnecessary intervention like hormonal treatment and surgery.

Funding: No funding sources

Conflict of interest: None declared

Ethical approval: The study was approved by the Institutional Ethics Committee

\section{REFERENCES}

1. Abers JR, Hull SK, Wesley RM. AUB. Am Fam Phy. 2004;68(8):1915-34.

2. Poppe K, Glinoer D. Thyroid autoimmunity and hypothyroidism before and during pregnancy.Human Reprod Update. 2003;9:149-161.

3. Thomas R, Reid RL. Thyroid diseases and reproductive dysfunction. Obstet Gynecol. 1987;70:789-98.

4. Gowri M, Radhika BH, Harshini V, Ramaiaha R. Role of thyroid function tests in women with abnormal uterine bleeding. Int $\mathrm{J}$ Reprod Contracept Obstet Gynecol. 2014;3(1):54-7.

5. Kochupillai N. Clinical endocrinology in India. Curr Sci. 2000;79:1061-7.

6. Hollowell JG, Stachling NW, Flanders WD, Hannon WH, Gunter EW, Spencer CA et al. Serum TSH, T4, and thyroid antibodies in the United States population (1988 to 1994): National Health and Nutrition Examination Survey (NHANES III). J Clin Endocrinol Metab. 2002;87(2):489-99.
7. Cappole AR, ladenson PW. Hypothyroidism and atherosclerosis. J Clin Endocrinol Metab. 2003;88:2438-44.

8. Byna P, Siddula S, Kolli S, Shaik MV. Thyroid abnormality in perimenopausal women with abnormal uterine bleeding. Int $\mathrm{J}$ Res Med Sci. 2015;3:3250-3.

9. Pilli GS, Sethi B, Dhaded AV, Mathur PR. Dysfun uterine bleeding. J Obstet Gynaecol Ind. 2001;52(3):87-9.

10. Sharma N, Sharma A. Thyroid profile in menstrual disorders. JK Sci. 2012;14(1):14-17.

11. Rani AS, Rekaha B, Reddy GA. Study of hypothyroidism in women with abnormal uterine bleeding. IOSR-JDMS. 2016;15(4):12-18.

12. Pahwa S, Shailja G, Jasmine K. Thyroid dysfunction in DUB. J Adv Res Bio Sci. 2013;5(1):78-839.

13. Padmahela K, Thomas V, Lawanya KM, Kiranmai D. Thyroid disorders in DUB among reproductive age group women- a cross sectional study in a tertiary care hospital in Andhra Pradesh India. Int J Med Pharma Sci. 2013;4(1):41-4610.

14. Kaur T, Asuja V, Sharma S. Thyroid dysfunction in AUB. Web Med Central Obstet Gynecol. 2011;2(9):1-7.

Cite this article as: Singh $\mathrm{P}$, Dubey $\mathrm{P}$, Yadav $\mathrm{S}$, Yadav SS. Thyroid abnormality in abnormal uterine bleeding: an observational study from Medical College in Western UP, India. Int J Reprod Contracept Obstet Gynecol 2018;7:308-11. 